\title{
IAMJ
}

INTERNATIONAL

AYURVEDIC

MEDICAL JOURNAL

\section{MANAGEMENT OF GUD BHRANSHA WITH KASISADI TAIL - A CASE STUDY}

\author{
Prasad Keshav Kakade ${ }^{1}$, Shilpa Badhe ${ }^{2}$ \\ ${ }^{1}$ (PG Scholar, Department of Shalyatantra) \\ ${ }^{2}$ (PROF \& HOD of Shalyatantra Department) \\ SMBT Ayurved College \& Hospital, Dhamangaon, Igatpuri, Maharashtra, India
}

Corresponding Author: prasadkakade75@gmail.com

\section{https://doi.org/10.46607/iamj3809112021}

(Published Online: November 2021)

Open Access

(C) International Ayurvedic Medical Journal, India

Article Received: 25/10//2021 - Peer Reviewed: 05/11/2021 - Accepted for Publication: 06/11/2021

\section{Check for updates}

\begin{abstract}
Gud Bhransha is a protrusion of mucous membrane of the Rectum from outside the anal verge with membrane or without membrane. It can be partial or complete. This condition is common in children and elderly patients. There are two types of treatment of rectal prolapse are conservative and surgical. The type of treatment of rectal prolapse depends on the severity of the disease. A clinical study was conducted on the patient of Gudbhransh with an elderly patient disease to evaluate the contraction effect of the Kasisadi tail which is traditionally practised in rural areas of Igatpuri, Maharashtra, India based on a survey. The aim and objective of this study were to evaluate the contraction effect of the Kasisadi tail over prolapsed rectal mucosa. Which was successfully treated by conservative Ayurvedic management Gudbhransh is treated in line with the treatment of Ayurveda as a complication of Atisar by the Kasisadi tail by anal route for correction of prolapse locally. The case result confirms that rectal prolapse can be managed effectively with Ayurvedic treatment in a short duration of time.
\end{abstract}

Keywords: Kasisadi Tail, Gudbhransh, Rectal prolapse, Atisar

\section{INTRODUCTION}

Gud Bhramsa/Rectal prolapse is most common in children, elderly patients, females with Torn perineum. It is afflicting mankind from ancient period \& equally spreader all over the world. In Indian society, children are low birth weight, weak, malnourished and are complained with intestinal worms, persons who 
have constant constipation or diarrhoea. Females with Torn perineum, weakness, Anemia and elderly people with low immunity \& age factor relaxes the pelvic muscles \& anal sphincters thus increasing the chances of prolapse. Due to all the above parameters, surgery is contraindicated in prolapse. In surgical done success rate of surgical procedures in Rectal prolapse is very low as reoccurrence or relapse rates are high and it does not correct the defect. Above Senior compulsive whole world towards scientific Ayurvedic approach in treating Rectal prolapse. Gud Bhransha/Rectal Prolapse is a protrusion of the mucous membrane or the entire rectum outside the anal verge.

AIM AND OBJECTIVES: To evaluate the efficacy of Kasishadi tail in the management of Gud Bhransha. MATERIAL AND METHODOLOGY

\section{Design of the study}

A clinical study was designed on conceptual literature review, as Kasishadi tail is used in Bleeding \& prolapsed mass of haemorrhoids, is as beneficial as in Gud Bhransha/Rectal Prolapse. Kasishadi oil is available very easily $\&$ broadly in every place.

\section{Material used:}

Kasisadi tail: It was prepared with Mineral drugs Kasish, Manashila, Hartaal along with Saindhava lavana and Gomutra and herbal drugs-langali, Kushta, shunti, Pippali, Ashwamara, Vidanga, Chitraka, Druma, Danti, Koshathaki Beeja, Hemahva, Snuhi, Processed in Tila Taila as per the standard Taila preparation methods.

Method of preparation: Kasishadi taila Basti was prepared. Kasisadi tail $(\approx 10 \mathrm{ml})$ It was made lukewarm by keeping it in hot water.

Time of Administration: Kasisadi Basti administered in the morning hours empty stomach followed by $\mathrm{T}$ Bandage (Gofhana Bandh).

Duration: Daily for 30 days; on empty stomach in the morning.

\section{CASE HISTORY}

A patient of a 60-year-old male came to OPD of Shalya Tantra Department of SMBT Ayurveda Hospital, Igatpuri with h/o fulfilling the sign \& symptoms of diagnostic criteria of Gud Bhransha (Partial Rectal prolapse) was selected.

\section{- Chief Complaint}

- Bleeding per rectum drop by drop for a few minutes for 3 weeks.

- Something coming out from anus for 4 weeks.

- Sticky discharge from the anus for 4 weeks.

- Pain, Itching \& Burning sensation after defecation for 3 months.

- Constipation for a year.

\section{- On Examination}

The patient was found partial rectal prolapse with the moderate size of the prolapsed mass.

- Investigations: Routine haematological tests like CBC, Erythrocyte sedimentation rate (ESR), Random blood sugar (RBS), HIV, HbsAg. coagulation Time (CT) Bleeding Time (BT) was carried out to assess the condition of the disease. All reports were within normal limits.

- Diet and restriction: Patient were advised to avoid overeating, repeated food, heavy food intake, spicy, and oily food, hence proper light food, high fibrous food was given. The patient was asked to avoid constant straining during defecation and suppression of urges i.e., stool.

- Assessment Criteria: The following parameters were assessed before and after the treatment.

Subjective Parameters: Pain, Itching \& Burning Sensation, Mucous discharge, constipation, Bleeding.

Objective Parameters: Degree of partial rectal prolapse, Size of prolapsed mass. 


\section{OBSERVATION AND RESULT}

\begin{tabular}{|c|c|c|c|}
\hline & 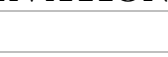 & Before Treatment & After Treatment \\
\hline 1 & \multirow[t]{5}{*}{ Symptoms } & moderate Pain & No Pain \\
\hline 2 & & moderate Itching \& Burning sensation & No Itching \& Burning sensation. \\
\hline 3 & & Mod. Mucous Discharge & No mucous discharge \\
\hline 4 & & Mild bleeding in few drops & No Bleeding \\
\hline 5 & & moderate Constipation & No constipation \\
\hline 1 & \multirow[t]{2}{*}{ Signs } & Moderate, Prolapsed & No prolapse \\
\hline 2 & & Mod. Size of prolapsed mass & Reduced prolapsed Mass \\
\hline
\end{tabular}

\section{DISCUSSION}

Gud Bransha is 'Vata vikara' with Mamsa Dhatu Dushti and for this Basti, oil is the best treatment. Kasisadi Taila possesses ushna, teekshna quality which acts as vata anulomana \& vata kafa hara thus manifesting in the decrease of constipation by reducing straining during defecation as well as the local inflammation by reducing itching \& pain. Kasis having varanaropana action, manashila \& saindhava was also beneficial in reducing burning sensation \& bleeding similarly Kasisa kashaya Rasa induces sandhana karma will have effective healing \& rakta sandana property thus reducing the bleeding and mucous discharge. Kasisadi taila having Kasisa, manashila and gomutra with kafavata hara property \& the majority of drugs having ushna teekshna veerya, rakta vikara shamana, vranaropana qualities act against the $K V$ dosha \& are absorbed through rectal mucosa \& thus observed to beneficial in reducing mucosal discharge, prolapse as well as the size of the prolapsed mass.

\section{CONCLUSION}

Gud Bransha is the commonest anorectal disorder commonly seen in children \& elderly people. The clinical signs \& symptoms of the Gud Bransha can be compared to partial mucosal Rectal prolapse of modern science. In all cases of subjective \& objective parameters of Gud Bransha, Kasisadi tail Basti was found more beneficial rather than other methods. Although wider $\&$ more elaborate multicentric study with a large sample size is required for authentication.

\section{REFERENCES}

1. Manipal manual of surgery, CBS publishers \& Distributors, New Delhi, chapter 29-Rectum \& Anal Canal, $2004 ; 454$.
2. Sushruta sanhita, Dr. A.D. Shastri, Chowkhamba sanskrit sansthan varanasi, ed. 13, SU. Ni, 2002; 13/63: 289.

3. Gada Nighrah, Arshorogadhikar.

4. Ras Tarangini, 21/241.

5. Sushruta sanhita, Dr. A. D. Shastri, Chowkhamba sanskrit sansthan varanasi, ed. 13, Su. Chi, 2002; 20: 6163.

\section{Source of Support: Nil \\ Conflict of Interest: None Declared}

How to cite this URL: Prasad Keshav Kakade \& Shilpa Badhe: Management Of Gud Bhransha With Kasisadi Tail - A Case Study. International Ayurvedic Medical Journal \{online\} 2021 \{cited November 2021\} Available from: http://www.iamj.in/posts/images/upload/2877_2879.pdf 